\title{
The Safety of Epigallocatechin-3-Gallate (EGCG) as a Potential Chemopreventative and Chemotherapeutic Agent in Hepatocarcinogenesis
}

\section{Dina Halegoua-De Marzio*}

Division of Gastoenterology and Hepatology, Thomas Jefferson University Hospital, Philadelphia, Pennsylvania, USA

Green tea, made from the unfermented leaves of Camellia sinensis, is one of the most widely consumed beverages in the world. It is comprised of several polyphenolic compounds (catechins) and can be concentrated into a Green Tea Extract (GTE), which, in turn, is a common ingredient in many dietary supplements. Epigallocatechin-3gallate (EGCG) is the most abundant and potent catechin contained within GTE, comprising typically $~ 40 \%$ of the total polyphenol content [1]. EGCG has antioxidant, antiviral, anticarcinogenic, antimutagenic and anti-inflammatory properties, shown in several preclinical and epidemiologic studies [2-6]. Preclinical data in cell culture and animal models suggest green tea may have a role as a chemopreventative agent for many types of cancer, including Hepatocellular Carcinoma [7-11]. Currently, there is a need for more effective treatments for hepatocellular carcinoma which occurs primarily in patients with viral hepatitis and cirrhosis. Given these easily identifiable risk factors, hepatocellular carcinoma is an ideal disease for the development of effective chemopreventative agents.

It is estimated that approximately $2 \%$ of the US population is infected with HCV; cirrhosis develops in $20 \%$ of those infected and HCC develops in $25 \%$ of cirrhotics [12]. The majority of patients who present with symptoms associated with HCC do not survive one year [13]. Recent data has demonstrated that successful eradication of HCV in patients with cirrhosis was associated with a reduction in the rate of hepatic decompensation, liver transplant, and liver-related death [14-17]. Although, patients with cirrhosis stand to benefit from HCV therapy the rates of Sustained Virological Response (SVR) are substantially lower in patients with cirrhosis compared with those without cirrhosis [17].

EGCG has been found to be a potent inhibitor of HCV entry in hepatoma cell lines as well as primary human hepatocytes. The effect was independent of the HCV genotype, and both infection of cells by extracellular visions and cell-to-cell spread was blocked [18,19]. Beyond its antiviral effect on $\mathrm{HCV}$, recent data indicate that the receptor tyrosine kinesis are one of the critical targets of EGCG to inhibit cancer cell growth. EGCG as has also be shown to modulate the expression of target genes which are associated with induction of apoptosis and cell cycle arrest in cancer cells [20]. EGCG's chemopreventative effect has been demonstrated in human subjects with chronic hepatitis B and a very high risk of hepatocellular carcinoma. In a randomized, doubleblinded, placebo-controlled trial of 124 individuals with sero-positive HBsAg and aflatoxin-albumin adducts showed a significant decrease of 8-hydroxydeoxyguanosine, a biomarker of oxidative DNA damage, after three months of green tea polyphenol intake [11].

Clinical investigations on the potential benefits of EGCG's antiinflammatory and anti-tumor properties in patients with cirrhosis are warranted. Although the safety and pharmacokinetics of EGCG in patients with cirrhosis has been partially described, there are concerns regarding a risk for hepatotoxicity with EGCG [21]. This is especially where such risk may be unpredictable due to differences in EGCG's disposition in this patient population as a result of the underlying liver disease. Reports of adverse effects, mainly hepatitis, associated with the consumption of green tea preparations have been published [2224]. The mechanism of the potential hepatotoxicity of GTE is unclear [24]. However the impact of a hepatotoxic event may be magnified in patients with preexisting liver disease as a result of alterations in pathways involved in EGCG's hepatic metabolism or excretion. Differences in the disposition of silymarin, another herbal product used by patients for the self-treatment of liver disease, has been seen in volunteers with liver disease $[25,26]$. Alterations in the expression of hepatobiliary transporters induced by liver disease, which may lead to differences in drug disposition, have been reported [27,28].

GTE is a common ingredient in several dietary supplements, some of which have been withdrawn from the market due to safety concerns. An example of this is when the manufacture of Exolise (Arkopharma, France), a weight loss supplement containing high EGCG levels was withdrawn from the market in April 2003 due to 13 cases of liver damage possibly due to its consumption [29]. Case series and a systematic review by the United States Pharmacopeia (USP) further illustrated evidence for the potential for green tea extract to cause hepatotoxicity [24]. Since 1966, 216 case reports of toxicity with green tea extracts were identified by the USP, of which 34 were concerning for liver toxicity. The majority of cases present with an acute hepatocellular injury pattern and most recover with cessation of use [22-24]. It was unclear in most case reports whether the toxicity was due to the green tea extract or possibly by the extraction process, concomitant medications, or from the other herbs in the supplements. Taking into account that most of the reported liver injuries involve women, a gender susceptibility to green tea hepatotoxicity may be hypothesized. An idiosyncratic or an immune-allergic mechanism appears to be the likely mechanism of injury [23]. Recent animal studies with high doses of GTE and EGCG have described dose dependent hepatotoxicity resulting in severe morbidity and mortality. However, chronic moderate to high dose daily GTE and EGCG use in healthy human volunteers was not shown to cause severe adverse effects or impair liver function [30].

In summary, EGCG has anti-angiogenic, anti-oxidant and antifibrotic properties that may have therapeutic potential in Hepatitis $\mathrm{C}$ Virus (HCV) induced cirrhosis. Given its potential role as adjunct to HCV therapy and as a chemopreventative agent in the HCV cirrhotic

*Corresponding author: Dina Halegoua-De Marzio, MD, Division of Gastoenterology and Hepatology, Thomas Jefferson University Hospital, Philadelphia, PA 19107, USA, E-mail: dina.halegoua@gmail.com

Received October 18, 2013; Accepted October 21, 2013; Published October 27 2013

Citation: Dina Halegoua-De Marzio (2013) The Safety of Epigallocatechin-3Gallate (EGCG) as a Potential Chemopreventative and Chemotherapeutic Agents in Hepatocarcinogenesis. J Liver 2: e106. doi:10.4172/2167-0889.1000e106

Copyright: (c) 2013 Dina Halegoua-De Marzio. This is an open-access article distributed under the terms of the Creative Commons Attribution License, which permits unrestricted use, distribution, and reproduction in any medium, provided the original author and source are credited. 
Citation: Dina Halegoua-De Marzio (2013) The Safety of Epigallocatechin-3-Gallate (EGCG) as a Potential Chemopreventative and Chemotherapeutic Agents in Hepatocarcinogenesis. J Liver 2: e106. doi:10.4172/2167-0889.1000e106

population, further study is needed in the safety and efficacy of EGCG in cirrhotic patients.

\section{References}

1. Yang CS, Landau JM (2000) Effects of tea consumption on nutrition and health. J Nutr 130: 2409-2412.

2. Demeule M, Michaud-Levesque J, Annabi B, Gingras D, Boivin D, et al. (2002) Green tea catechins as novel antitumor and antiangiogenic compounds. Curr Med Chem Anticancer Agents 2: 441-463.

3. Ahn HY, Hadizadeh KR, Seul C, Yun YP, Vetter H, et al. (1999) Epigallocathechin-3 gallate selectively inhibits the PDGF-BB-induced intracellular signaling transduction pathway in vascular smooth muscle cells and inhibits transformation of sis-transfected NIH 3T3 fibroblasts and human glioblastoma cells (A172) Mol Biol Cell 10: 1093-1104.

4. Sung $H$, Nah J, Chun S, Park H, Yang SE, et al. (2000) In vivo antioxidant effect of green tea. Eur J Clin Nutr 54: 527-529.

5. Ahmad N, Feyes DK, Nieminen AL, Agarwal R, Mukhtar H (1997) Green tea constituent epigallocatechin-3-gallate and induction of apoptosis and cell cycle arrest in human carcinoma cells. J Natl Cancer Inst 89: 1881-1886.

6. Bushman JL (1998) Green tea and cancer in humans: a review of the literature. Nutr Cancer 31: 151-159.

7. Sun CL, Yuan JM, Koh WP, Yu MC (2006) Green tea, black tea and breas cancer risk: a meta-analysis of epidemiological studies. Carcinogenesis 27 : $1310-1315$.

8. Sun CL, Yuan JM, Koh WP, Yu MC (2006) Green tea, black tea and colorectal cancer risk: a meta-analysis of epidemiologic studies. Carcinogenesis 27: 1301-1309.

9. Mann CD, Neal CP, Garcea G, Manson MM, Dennison AR, et al. (2009) Phytochemicals as potential chemopreventative and chemotherapeutic agents in hepatocarcinogenesis. European Journal of Cancer Prevention 18:13-25.

10. Lamy S, Gingras D, Béliveau R (2002) Green tea catechins inhibit vascular endothelial growth factor receptor phosphorylation. Cancer Res 62: 381-385

11. Luo H, Tang L, Tang M, Billam M, Huang T, et al. (2006) Phase Ila chemoprevention trial of green tea polyphenols in high-risk individuals of liver cancer: modulation of urinary excretion of green tea polyphenols and 8-hydroxydeoxyguanosine. Carcinogenesis 27: 262-268.

12. El-Serag HB, Mason AC (1999) Rising incidence of hepatocellular carcinoma in the United States. N Engl J Med 340: 745-750.

13. Mann CD, Neal CP, Garcea G, Manson MM, Dennison AR, et al. (2009) Phytochemicals as potential chemopreventive and chemotherapeutic agents in hepatocarcinogenesis. Eur J Cancer Prev 18: 13-25.

14. Mallet V, Gilgenkrantz H, Serpaggi J, Verkarre V, Vallet-Pichard A, et al. (2008) Brief communication: the relationship of regression of cirrhosis to outcome in chronic hepatitis C. Ann Intern Med 149: 399-403.

15. Bruno S, Strofolini T, Colombo M, Bollani S, Benvegnù L, et al. (2007) Sustained virological response to Interferon-alpha is associated with improved outcome in HCV-related cirrhosis: a retrospective study. Hepatology 45: 579-587.
16. Hung $\mathrm{CH}$, Lee $\mathrm{CM}$, Lu SN, Wang JH, Hu TH, et al. (2006) Long-term effect of interferon alpha-2b plus ribavirin therapy on incidence of hepatocellular carcinoma in patients with hepatitis $C$ virus-related cirrhosis. J Viral Hepat 13 409-414.

17. Veldt BJ, Heathcote EJ, Wedemeyer H, Reichen J, Hofmann WP, et al. (2007) Sustained virologic response and clinical outcomes in patients with chronic hepatitis C and advanced fibrosis. Ann Intern Med 147: 677-684.

18. Calland N, Albecka A, Belouzard S, Wychowski C, Duverlie G, et al. (2012) (-)-Epigallocatechin-3-gallate is a new inhibitor of hepatitis $C$ virus entry. Hepatology 55: 720-729.

19. Ciesek S, von Hahn T, Colpitts CC, Schang LM, Friesland M, et al. (2011) The green tea polyphenol, epigallocatechin-3-gallate, inhibits hepatitis $C$ virus entry. Hepatology 54: 1947-1955.

20. Shimizu M, Shirakami Y, Moriwaki H (2008) Targeting receptor tyrosine kinases for chemoprevention by green tea catechin, EGCG. Int J Mol Sci 9: 1034-1049.

21. Halegoua-De Marzio D, Kraft WK, Daskalakis C, Ying X, Hawke RL, et al (2012) Limited sampling estimates of epigallocatechin gallate exposures in cirrhotic and noncirrhotic patients with hepatitis $C$ after single oral doses of green tea extract. Clin Ther 34: 2279-2285.

22. Shim M, Saab S (2009) Severe hepatotoxicity due to Hydroxycut: a case report Dig Dis Sci 54: 406-408.

23. Mazzanti G, Menniti-Ippolito F, Moro PA, Cassetti F, Raschetti R, et al. (2009) Hepatotoxicity from green tea: a review of the literature and two unpublished cases. Eur J Clin Pharmacol 65: 331-341.

24. Sarma DN, Barrett ML, Chavez ML, Gardiner P, Ko R, et al. (2008) Safety of green tea extracts a systematic review by the US Pharmacopeia. Drug Saf. 31:469- 484.

25. Schrieber SJ, Wen Z, Vourvahis M, Smith PC, Fried MW, et al. (2008) The pharmacokinetics of silymarin is altered in patients with hepatitis $C$ virus and nonalcoholic Fatty liver disease and correlates with plasma caspase-3/7 activity. Drug Metab Dispos 36: 1909-1916.

26. Schrieber SJ, Hawke RL, Wen Z, Smith PC, Reddy KR, et al. (2011) Differences in the disposition of silymarin between patients with nonalcoholic fatty liver disease and chronic hepatitis C. Drug Metab Dispos 39: 2182-2190.

27. Lake AD, Novak P, Fisher CD, Jackson JP, Hardwick RN, et al. (2011) Analysis of global and absorption, distribution, metabolism, and elimination gene expression in the progressive stages of human nonalcoholic fatty liver disease. Drug Metab Dispos 39: 1954-1960.

28. Chow HH, Cai Y, Hakim IA, Crowell JA Shahi F, et al (2003) Pharmacokinetics and safety of green tea polyphenols after multiple-dose administration of epigallocatechin gallate and polyphenon $E$ in healthy individuals. Clin Cancer Res 9: 3312-3319.

29. Seddik M, Lucidarme D, Creusy C, Filoche B (2001) [ls Exolise hepatotoxic?] Gastroenterol Clin Biol 25: 834-835.

30. Foster DR, Sowinski KM, Chow HH, Overholser BR (2007) Limited sampling strategies to estimate exposure to the green tea polyphenol, epigallocatechin gallate, in fasting and fed conditions. Ther Drug Monit 29: 835-842. 